\author{
Svitlana Matviienkiv \\ Vasyl Stefanyk Precarpathian National University (Ivano-Frankivsk, Ukraine) \\ https://orcid.org/oooo-ooo2-7719-7791 \\ e-mail: smatvienkiv@gmail.com
}

\title{
THE PRESS OF NATIONAL MINORITIES OF MODERN UKRAINE (ON THE EXAMPLE OF IVANO-FRANKIVSK)
}

\section{Abstract}

Media of national minorities contribute to observance of principles of civil society and to strengthening of tolerance and stability in Ukrainian multiethnic society. Therefore, their study became the purpose of this article.

The research was made on the basis of philosophical, general scientific and specific methods of scientific research. A key method was the comparative critical analysis of the activities of public organizations and private media of national minorities of modern Ukraine considering the Carpathian region. In addition, the methodological foundation of the research is based on General scientific methods of research of problems of national minorities' rights fulfillment to their own media in modern Ukrainian society.

It is demonstrated that registered periodicals and Polish national minorities' of the Carpathian region radio speech is the evidence of the existence of a free non-governmental organizations that reflect interests of social groups and their values. Polish community is dispersed, so the tendency of its social media development reflects all-Ukrainian ethnic-integration state of representatives of the national communities into the society. Polish-speaking and bilingual newspapers and magazines of Ivano-Frankivsk region are important factors of preservation and public expression of identity of national minorities and reflect their unique culture, traditions, and the degree of their assimilation.

Permanent publishing of government-approved national periodicals provides an opportunity for representatives of national minorities to feel equal citizens of Ukraine with a high social status and provided cultural demands. The existence of periodicals of national minorities raises awareness of society, promoting national reconciliation, mutual understanding between people, development of society.

Keywords: national minorities, periodicals, public organizations, polyethnic society, legislation, tolerance. 


\section{Матвієнків Світлана Миколаївна}

ДВНЗ «Прикарпатський національний університет імені Василя Стефаника» (м. Івано-Франківськ, Україна)

https://orcid.org/oooo-ooo2-7719-7791

e-mail: smatvienkiv@gmail.com

\section{ПРЕСА НАЦІОНАЛЬНИХ МЕНШИН СУЧАСНОЇ УКРАЇНИ (НА ПРИКЛАДІ М. ІВАНО-ФРАНКІВСЬКА)}

\section{Резюме}

Медіа національних меншин сприяють дотриманню принципів громадянського суспільства і укріпленню толерантності та стабільності в українському поліетнічному суспільстві. Тому їх дослідження і стало метою даної статті.

Для цього застосовувалися філософські, загальнонаукові та специфічні методи наукового дослідження. Ключовим методом став порівняльнокритичний аналіз діяльності громадських організацій та власних медіа національних меншин сучасної України на прикладі Прикарпаття. Крім того, методологічна основа дослідження базується на загальнонаукових методах досліджень проблеми реалізації прав національних меншин на власні медіа у сучасному українському суспільстві.

Показано, що зареєстровані періодичні видання та радіо польської національної меншини Прикарпаття є свідченням вільного існування недержавних організацій, які відображають інтереси соціальних груп та їх цінності. Польська громада $\epsilon$ дисперсною, тому тенденція розвитку іiі 3МI відображає всеукраїнський стан етноінтеграції представників національних громад у суспільство. Польськомовні та двомовні газети й журнали Івано-Франківщини $\epsilon$ важливим чинником збереження і прилюдного вираження ідентичності національних меншин та відображають як самобутність культури й традицій, так і ступінь їх асиміляції.

Постійний вихід схваленої державою національної періодики дає можливість представникам національних меншин почуватися рівноправними громадянами України з високим соціальним статусом та забезпеченими культурними запитами. Існування періодичних видань національних 
меншин підвищує рівень поінформованості суспільства, сприяє національному примиренню, порозумінню між людьми, розвитку громадянського суспільства.

Ключовіслова:національніменшини,періодичнівидання,громадські організації, поліетнічне суспільство, законодавство, толерантність.

\section{Bcmyn}

Національною меншиною вважається група людей некорінного етнічного статусу, які живуть у сучасному для себе етносередовищі. Національна меншина включає осіб, які мають громадянство i, за визначенням, не відіграють провідної ролі в суспільстві, що зумовлює необхідність відстоювання політичних прав і забезпечення відповідного юридичного захисту. Національна меншина поступається чисельністю іншим етнічним групам, але має достатньо сил для впливу на політичну ситуацію регіонів проживання. Прагнучи зберегти ідентичність етнічну, національна меншина створює спеціальні інституції, національні, культурні центри, освітні установи, 3МI [1].

Важливою ознакою сучасного світу є поліетнічність національного складу населення багатьох країн, яка сталась унаслідок зміни політичної карти світу після двох світових воєн та посилення міграційних процесів через локальні конфлікти чи з економічних причин. Така поліетнічність потребує як законодавчого врегулювання, так і суспільного прийняття. Тому актуально, з погляду європейського спрямування України, розглянути виявлення ідентичності та самобутності національних меншин через їх періодичні видання [2, с. 64].

\section{Методи дослідження}

У статті застосовувався увесь комплекс філософських, загальнонаукових, та специфічних методів наукового дослідження, які притаманні сучасній науці, у їх взаємозв’язку й взаємодоповнюваності. Ключовим методом став порівняльно-критичний аналіз діяльності громадських організацій та власних медіа національних меншин сучасної України на прикладі Прикарпаття. Крім того, методологічна основа дослідження базується на загальнонаукових методах досліджень проблеми реалізації прав національних меншин на власні медіа у сучасному українському суспільстві, зокрема емпіричному, компаративістському, аналітичному та дескриптивному.

\section{Результати}

За даними Всеукраїнського перепису населення 2001 року, на території України проживають представники понад 130 національностей і народностей. У національному складі населення переважна більшість -українці, чисельність яких становила 37541,7 тис. осіб, або 77,8\% від загальної кількості населення. Друге місце за чисельністю посідали росіяни. Їхня 
кількість - 8334,1 тис. осіб, або 17,3\%. У п'ятірку найбільших національних спільнот, які проживають на території України, разом із росіянами, входять білоруси, молдавани, кримські татари та болгари. У другу п’ятірку-угорці, румуни, поляки, євреї, вірмени [3, с.5].

25 червня 1992 Верховна рада України ухвалила Закон «Про національні меншини в Україні» [4], який не лише враховував специфіку етнонаціонального розвитку України, а й міжнародний досвід регулювання міжнаціональних взаємин. Ухвалення даного закону мало принципове значення для перспектив держави, оскільки була задекларована побудова поліетнічного демократичного правового суспільства. Права національних меншин були зафіксовані і в Конституції України 1996 року. У суверенній Україні ратифіковані міжнародні правові документи, що регулюють становище національних меншин у поліетнічних суспільствах: Європейська конвенція про захист прав і основних свобод людини (1997p. ), Рамкова конвенція про захист національних меншин (1995р. ), ст. 9 якої надає право на отримання та поширення інформації рідною мовою як всередині країни, так і за їі межами, яке реалізується перш за все через можливість створення власних засобів масової інформації, що виходять національною мовою. Від 1 січня 2006 р. в Україні вступила в дію Європейська хартія регіональних мов або мов меншин (1992р. ). Для координації державотворчого потенціалу національних меншин у травні 1996 р. при Міністерстві України у справах національностей та міграції була створена Рада представників громадських об'єднань національних меншин. Від 19 квітня 2000 при Президентові України діяла Рада представників громадських об'єднань національних меншин, яка сприяла підвищенню ролі громадських організацій національних меншин у розробці державної політики та розбудові української державності. Рішення ради мали рекомендаційний характер, робота їі забезпечувалася Міністерством юстиції України. У 2001 році створено Державний комітет України в справах національностей та міграції [1]. Станом на початок 2019 р. не існує окремого міністерства чи державного комітету, який опікувався би питаннями національних меншин. Натомість $\epsilon$ відповідний департамент при Міністерстві культури України, а також відповідні відділи чи департаменти при обласних державних адміністраціях у різних регіонах.

В Україні традиційно проживали й проживають і компактно, і дисперсно представники різних національних меншин, які економічно, соціально, культурно взаємодіють з українцями та намагаються, залежно від обставин, або зберегти свою ідентичність, або асимілюватись. Тому сучасні українські дослідники, зокрема Г. Луцишин, зосереджують увагу на місці й ролі національних меншин у політичному житті України, зазначаючи, що забезпечення задекларованих прав і свобод національних меншин $\epsilon$ неодмінною умовою як національної консолідації, так й успішної зовнішньої 
політики України [5,6]. Дослідники І. Лопушинський та І. Попова наголошують на необхідності співпраці з національними меншинами для досягнення толерантності в суспільстві [7]. Історіографічна праця О. Рафальського охоплює різні інтерпретації поглядів, починаючи від царської Росії, реалій політики «коренізації» 20-30-х pp. XX ст., бездієву декларативність радянської імперії щодо формування демократичної незалежної України [8]. Чирко Б. В. та Орлянський В.С. характеризують національні меншини України початку XX ст. [9]. Миронова I. [10] та Ю. Колісник досліджують пресу національних меншин в умовах становлення української державності [11]. Праці Н. Мяловицької [12] та Рябошапка Л. присвячені правовому становищу національних меншин України [13].

Щодо громадських організацій національних меншин, то вони виступають, як правило, лише тлом досліджень політико-правових аспектів захисту прав національних меншин (О. Антонюк, Н. Беліцер, В. Никитюк, Ю. Римаренко, М. Шульга, Л. Шкляр). Сучасні дослідники Якубова Л.Д., Швець В.М., Безверха Т. М., Дуцик Д., Дворовий М. у своїх працях розглядають пресу національних меншин України як чинник етнічної консолідації суспільства.

Тому метою статті $\epsilon$ визначення особливостей діяльності періодичних видань національних меншин України, зокрема ІваноФранківщини, для відродження й збереження своєї національної ідентичності та інтересів, для консолідації в українське суспільство. Завданням є визначення ступеня дотримання задекларованих прав і свобод, суспільної та політичної активності національних меншин, вираження своєї ідентичності та самобутності в періодичних виданнях.

Україна як держава через Конституцію та закони гарантує всім народам, національним групам, громадянам, які проживають на її території, рівні політичні, економічні, соціальні та культурні права. Дискримінація за національною ознакою заборонена і карається відповідно до закону. Толерантність формується під впливом цілого комплексу чинників. Медіа в цьому процесі відіграють одну із ключових ролей. Значною мірою саме від них залежить формування комунікаційних практик всередині суспільства між різними групами, а відповідно і суспільний клімат загалом. Представники національних меншин не можуть зазнавати дискримінації та, зокрема, ставати об’єктами мови ворожнечі. Держави мають сприяти доступу представників меншин до медіа, а також заохочувати створення і трансляцію телерадіопрограм мовами національних меншин. Журналісти зокрема, як і медіа в цілому, повинні зберігати неупередженість у висвітленні тем, пов'язаних із меншинами. Це дозволяє поглянути на проблеми з різних ракурсів та перспектив [3, с. 6].

Громадські об’єднання національних меншин є неурядовими організаціями, які відображають етнічні, соціальні, культурні інтереси їх 
представників. Важливим засобом вираження таких інтересів $\epsilon$ традиційні та сучасні медіа. Друковані етнічні ЗМІ відіграють важливу роль у ствердженні демократії, миру та злагоди в країні, реально сприяють реалізації європейських норм і стандартів в етнополітиці багатонаціональної України [14].

За час свого існування (із жовтня 1991року) газети національних меншин переживали неодноразову реорганізацію - були додатками до газети Верховної Ради України «Голос України», потім передані Державному комітету України у справах національностей та міграції. 32011 року державна підтримка газет належала до компетенції Міністерства культури України. Згідно Закону «Про реформування державних та комунальних друкованих 3MI» у 2018 році Міністерство культури видало наказ про вихід зі складу співзасновників друкованих 3МІ. Газети національних товариств мають виключно просвітницьке спрямування (висвітлюють культурну, освітню та соціальну сфери, спрямовані на захист національної мови, звичаїв) і не можуть конкурувати із суспільно-політичними виданнями, а тим більше з комерційними. Тому без державної підтримки ця важлива для держави програма - видання газет мовами національних меншин - icнувати не може [15].

У 2004 році в Україні виключно україномовних видань було зареєстровано 4084, російськомовних - 2620, угорськомовних - 10, польськомовних -4 , румунськомовних -6 , кримськотатарськомовних -4 , англомовних -27 , болгарськомовних -2 , німецькомовних -2 [16].

За даними Державного комітету телебачення і радіомовлення України вже у 2019 році загальна кількість друкованих видань становила 3143, 3 них газет-1371, а решту - періодичні і продовжувані видання. Українською мовою виходить 1321 видання, з них газет-781; російською - 3 497 видань зареєстровано 289 газет; англійською мовою виходить 67 видань, з яких тільки 2 газети; угорською -5 газет; польською-3 газети; румунською-2 газети; вірменською-1, а решту - дво-чи тримовні [17]. Тобто газети мовами національних меншин складають $38,6 \%$ від загальної кількості по Україні. Розглянемо детальніше по областях.

Книжкова палата України у 2019 році зареєструвала в ІваноФранківській області тільки одну газету польською мовою-«Kurier Galicyjski» («Кур’єр Галіційський»). У Дніпропетровській області щомісячно російською мовою виходить «Шабат Шалом» - місцева єврейська газета. У Донецькій області у Маріуполі Федерація грецьких спільнот України видає «Эллины Украины» - щомісячну загальнодержавну газету українською і російською мовою. Закарпатська область вирізняється тим, що тут зареєстровано 5 місцевих газет угорською мовою («Karpatalja», «KARPATI IGAZ SZO», «Karpatinfo», «Naplopo», «Vitamin+») та 2 українською і угорською («Nagyszolos-videki Hirek», «Новини Виноградівщини»). У Львівській 242 
області виходить два щомісячники українською та російською мовою: «Хесед-Ар'є»-регіональний бюлетень Всеукраїнського єврейського благодійного фонду та «Шофар»-місцеве видання Львівського товариства єврейської культури імені Шолом-Алейхема. В Одеській області зареєстрована щотижнева загальнодержавна газета «Роден край» (Всеукраински културно-просветен вестник на българите в Украйна), яка виходить українською та болгарською мовою. Чернівецька область: «Monitorul de Hliboca» («Новий день») i «Meleag natal» («Рідний край») - щотижневі місцеві газети румунською мовою та «Хесед Шушана» («Троянда милосердя») - місцевий бюлетень українською та російською мовою Чернівецького обласного єврейського благодійного фонду. Місто Київ-центр друкованих видань національних меншин України: вірменською мовою виходить загальнодержавний щомісячник «Upuguo» та «Арагац»-газета вірменської національної меншини України українською та російською мовою; «Dziennik Kijowski» (Pismo spoleczne, ekonomiczne i literackie) та «Wolnosc i Prawo»-загальнодержавні видання польською мовою; «Єврейські вісті» - загальнодержавна газета єврейської ради України українською мовою та «Хадашот»- щомісячна газета російською мовою Асоціації єврейських організацій і спільнот України; «Форум націй»-щомісячна газета українською мовою Конгресу національних громад України [18]. Як бачимо, в сучасній Україні кількість друкованих видань національних меншин є достатньою, а чисельність залежить від регіонів їх проживання.

Прикарпаття є одним з регіонів України, де традиційно проживали й проживають представники різних національних меншин, які економічно, соціально, культурно взаємодіють з українцями та намагаються, залежно від обставин, або зберегти свою ідентичність, або асимілюватись.

У національному складі населення Івано-Франківської області у 2001 році переважали українці, яких нараховувалося 1371,2 тис. осіб або 97,5 \% від загальної кількості населення (1409,8 тис. ). Тут також проживають представники понад 90 національностей і народностей: росіяни -24,9 тис. (їх кількість порівняно з переписом 1989 року зменшилась на 56,3 \% ), поляки - 1,9 тис., білоруси $-1,5$ тис., молдовани - о,6 тис., євpeї-0,4 тис., угорці-0,1 тис. та ін. [19].

90 років тому Станиславів і загалом Західна Україна входили до складу Другої Речі Посполитої, поляки, як і євреї, становили левову частку мешканців теперішнього Івано-Франківська (майже 22 тис. ), в той час, як українців у Станиславові налічувалося всього 8,5 тис. Упродовж 70 наступних років - війни, репатріація і комуністичний режим - все докорінно змінилося. Тепер українці мають власну незалежну державу і $є$ український за складом і ментальністю Івано-Франківськ, хоча польська стара архітектура і часто традиції передалися йому в спадок. У Станиславові (до 1962 року ще зберігалася польська назва міста) в кожному кіоску можна 
було купити різні польські часописи і газети, i їх купували й виписували не тільки поляки, а й українці. Перша газета в Івано-Франківську «Дзєннік Станіславовскі» почала виходити 2 вересня 1848 р. Після переїзду зі Львова українця Івана Данкевича в місті почали швидкими темпами розвиватися польські видавництва газет та часописів. Так, протягом 1836-1883 рр. виходила газета «Кур'єр Станіславський» (засновником і першим редактором був Агатон Гіллер, один з керівників польського повстання 1863-1864 pp. ), незабаром - «Бігун Станиславівський» (1873р. ), «Гасло» (1875р. ), «Газета Підкарпатська» (1876 р. ), «Хроніка» (188ор. ), «Голос Станиславівський» (1881 р.), «Ехо Покуття» (1883 р. ), «Хроніка Станиславівська» (1885p. ), брошура для дітей: «Світелко» (1883 р. ).

Були іукраїнські видання: перша українська газета в місті «Господарь и Промышленник» (1879-1882 pp. ), часопис «Денниця» (188op. ), який редагував відомий український мовознавець Іван Верхратський. Після створення єпархії вийшов «Вісник Станіславської єпархії» (1886-1939рр. ) та «Богословський альманах» (1887p. ). 5 листопада 1918 р. почав виходити «Станіславський вісник»-урядовий часопис Повітової Української Національної Ради, а з 10 листопада - «Українське життя». У 1919 р. створено опозиційну до уряду ЗУНР газету «Республіканець», редактором якої був житель м. Станіслава Д. Дем'янчук. Загалом, у 1918-1919 рр. у Станіславі, тимчасовій столиці ЗУНР, виходило 13 українських часописів [20].

23 лютого 1919 року віддруковано перший номер польського тижневика «Głos prawdy» («Голос правди»), в якому було заявлено: Ми національна меншість і повинні з тим рахуватись... вважаємо святим обов'язком не дратувати розпаленого антагонізму народів, не будувати доріг, що нас ділять, а шукати тих, які би нас об'єднували. Будувати мости над прірвами...» [21].

У 1938 p. було проведено статистичний аналіз, який показав, що станом на 1934 р. у місті проживало більше 85 тис. жителів, із них: 46\% (40 тис.) євреїв, 36\% (25 тис. ) поляків, 16\% (20 тис. ) українців та 2\% -інших національностей. У цей період у Станіславі виходило 14 періодичних видань, із них 6 українською, 6 польською, 1 німецькою, 1 єврейською мовами [22].

Зараз в Івано-Франківській області загальна кількість місцевих та регіональних газет - 43, а в самому місті виходить 18 газет (наймасовіші «Галичина», «Західний кур'єр», «Галицький кореспондент») і 3 журнали та тільки одна з них - польською мовою - «Kurier Galicyjski».

Сучасна польська спільнота в м. Івано-Франківську та області $\epsilon$ не надто великою і становить національну меншину, проте вона активно розвивається, про що свідчать численні польські товариства. Так, із загальної кількості (38) зареєстрованих громадських організацій національних меншин на Прикарпатті, найчисельнішою громадою є поляки - 18 органі- 
зацій, потім німці-6, євреї-3, а решта (росіяни, румуни, угорці, словаки, білоруси, литовці, араби та ін. ) мають по одній організації.

Перепис населення у 2001 році показав, що в місті Івано-Франківську мешкає близько двох тисяч етнічних поляків (на 250 тисяч мешканців). Польська спільнота найчисельніша серед інших меншин і досить активна. У місті працюють такі громадські організації: Обласне Товариство польської культури імені Францішка Карпінського, Товариство польської культури «Пшиязнь», польсько-українська молодіжна організація «Млоди Станіславув», «Родина польська і Європа», Польське товариство імені Анджея Потоцького, Центр польської культури та європейського діалогу. У статутах цих організацій прописана підтримка і популяризація польської культури, мови, традицій та розвиток українсько-польських стосунків [23].

Головна мета Центру польської культури та європейського діалогу, який створений у 2013 році (став платформою для взаємодії всіх польських організацій) та $\epsilon$ найактивнішим у м. Івано-Франківську-це заклик до громадської активності польського середовища в усіх сферах діяльності задля зміцнення позитивної репутації Польщі в Україні; дбати про охорону прав польської національної меншини на території Західної України; налагоджувати взаєморозуміння між поляками й українцями. Центр має свою бібліотеку, передплачує 25 найпопулярніших у Польщі журналів, всі події, новини, оголошення висвічує на своєму інтернет-сайті. При Центрі функціонує радіо CKPiDE, яке фінансується Польщею, виходить двічі на місяць в ефір, а кожного тижня подає огляд українських та польських медіа двома мовами [24].

Громадяни України польського походження, що проживають на території Івано-Франківської області, активно долучаються до формування позитивного зовнішньополітичного іміджу України в Республіці Польща, оскільки їх права не лише декларовано, а й дотримано: немає перешкод в оприлюдненні національної ідентичності, вивченні рідної мови, сповідуванні римо-католицизму.

Також реалізовано їх права на власні медіа. «Kurier Galicyjski» - зареєстрована у м. Івано-Франківську найбільша регіональна газета польською мовою в Україні, яка виходить двічі на місяць. «Кур’єр Галіційський» визначає себе як незалежну газету для поляків в Україні. Частина редакції розташована у Львові, частина в Івано-Франківську. Газета фінансується за кошти Міністерства закордонних справ Польщі за посередництвом фундації «Свобода і демократія» (пол. Wolność i Demokracja) [25].

Це повністю незалежне видання, яке дотримується принципів вільної преси. Газета відкрита до співпраці з польським, і не лише польським середовищем, організаціями та іншими об'єднаннями, хоча перші, зі зрозумілих причин, є пріоритетними. Культурно-освітнє спрямування видання 
сприяє співдружності польського та українського народів, їх національному примиренню, зокрема в питаннях історичної пам'яті, адже матеріали газети висвітлюють сторінки історії поляків в Україні. Метою видання є популяризація польської мови, історії та культури серед громадян України польського походження. Крім паперової версії, газета виходить в електронній версії, під цією назвою діє теж радіо і телебачення [26].

Засновником і видавцем, головним редактором «Kurier Galicyjski» був Мірослав Ровіцький, член Союзу польських журналістів. Він брав активну участь у польсько-українській співпраці. 32005 року Мірослав Ровіцький активно підтримував етнічних поляків, які мешкають в Україні. 3 його ініціативи також засновано дитячий часопис польською мовою «Polak Mały». У 2015 році він увійшов у рейтинг найбільш заслужених для польсько-українського діалогу осіб. Мірослав Ровіцький був ініціатором створення Клубу Галіцийського - організації, до якої належать польські та українські публіцисти, журналісти, науковці, з його ініціативи теж проводилися щорічні польсько-українські наукові конференції у місті Яремче Івано-Франківської області. Він активно діяв у спільній ініціативі Прикарпатського національного університету та Варшавського університету - відбудові давньої астрономічної обсерваторії на горі Піп Іван [27].

Отже, поляки Івано-Франківщини, як і інші етнічні меншини, інтегровані в громадянське суспільство України у регіональному вимірі не тільки через громадські організації, а також і через регулярний випуск періодичних видань, які висвітлюють діяльність громадських об'єднань, культурних товариств та окремих представників меншин у житті регіону. Попри те, що «Кур’єр Галіційський» $є$ культурно-просвітнім виданням, редакції вдається відігравати важливу роль в етнічній консолідації поляків на Прикарпатті.

Крім польської, однією з активних меншин є також угорська община на Прикарпатті-це біля сотні осіб. На початку 2020 року в ІваноФранківську був створений Угорський культурно-освітній центр, основною метою роботи якого є впровадження просвітницької, наукової, культурної діяльності, що спрямована на поширення та ознайомлення населення краю з культурною спадщиною, традиціями, історією угорського народу та його зв'язків з українським народом. Він організовує виставки, відпочинок дітей та пошукові роботи з перепоховання угорських воїнів, які загинули в першій і другій світових війнах, та багато іншого. Висвітлюють свою діяльність у соцмережах, мають сторінку у Фейсбуку [28].

\section{Висновки}

Таким чином, періодичні видання національних меншин України репрезентують безперешкодно реалізоване належне інформаційне забезпечення їх представників, це $\epsilon$ свідченням повного дотримання 
задекларованих у Законі України «Про національні меншини в Україні» їх прав і свобод, а також повного суспільного прийняття та високого ступеня міжнаціональної толерантності. Етноінтеграція в українське суспільство відбувається в умовах рівноправного міжкультурного діалогу з відродженням й збереженням національної ідентичності та інтересів. Етнічні медіа України регулярно висвітлюють високий ступінь суспільної та політичної активності національних меншин, вільне вираження своєї ідентичності та самобутності. Постійний вихід схваленої державою національної періодики дає можливість представникам національних меншин почуватися рівноправними громадянами України з високим соціальним статусом та забезпеченими культурними запитами. Існування періодичних видань національних меншин підвищує рівень поінформованості суспільства, сприяє національному примиренню, порозумінню між людьми, гасить прояви побутової ксенофобії [2]. Проте, як уже зазначалося, зі зменшенням державної підтримки з боку України видання газет мовами національних меншин є неможливим. Їх діяльність підтримується фінансуванням держав національних меншин. Також важливою причиною зменшення кількості 3МІ національних меншин в Україні є міграція населення у свої етнічні держави та молоді за кордон.

\section{Список посилань:}

1. Якубова Л.Д. Національні меншини України. Енциклопедія історії України: Т. 7: Мі-О / Редкол.: В. А. Смолій (голова) та ін. НАН України. Інститут історії України. К.: В-во «Наукова думка», 2010. 728 c. URL: http://www. history. org. ua/?termin=Natsionalni_ menshyny (дата звернення: 01.07.2020)

2. Безверха Т.М. Періодичні видання національних меншин Житомирської області як чинник етноінтеграції громадянського суспільства в Україні. Наукові записки Інституту журналістики. 2016. T. 63. С. 64-67. URL: http://nbuv. gov. ua/UJRN/ Nzizh_2016_63_14 (дата звернення: 03.07.2020)

3. Дуцик Д., Дворовий М.Національні меншини України і медіа: до порозуміння через толерантність. Київ: ТОВ «СІГМАТРЕЙД», 2019. C. 5 .

4. Закон України «Про національні меншини в Україні» URL: http://zakon2.rada. gov. ua/laws/show/2494-12 (дата звернення: 04.07.2020)

5. Луцишин Г. I. Національні меншини у політичному житті України: дис.... канд. політ. наук. Львів, 2002. 190 с.

6. Луцишин Г. I. Національна консолідація України в умовах сучасного політичного процесу. Львів: Видавництво Львів. Політехніки, 2012. 361 с. 
7. Лопушинський І.П. Україна i національні меншини: шлях до толерантності та співпраці. Актуальні проблеми державного управління педагогіки та психології. Збірник наукових праць Херсонського національного технічного університету. Херсон, 2013. Вип. 1 (9). С. 99-103.

8. Рафальський О.О. Національні меншини в Україні в ХХ столітті: історіографія: дис.... д-ра іст. наук. К., 2001. 462 с

9. Чирко Б. В. Національні меншини України (20-30 роки XX ст. ). К.: Асоціація «Україна», 1995.

10. Міронова І. С. Національні меншини України. Миколаїв; Одеса: ТОВ ВіД, 2006. 305 с.

11. Колісник Ю. В. Преса національних меншин України як засіб їх самоствердження в умовах становлення української державності (1992-1999 рр. ): дис... канд. філол. наук. Львів, 2000. 173 с.

12. Мяловицька Н. Права національних меншин: європейський досвід. URL: http://www. viche. info/ journal/3839/. (дата звернення: 09.07.2020)

13. Рябошапка Л. Правове становище національних меншин України (1917-2000). Львів, 2001.

14. Швець В.М. Преса національних меншин України як чинник етнічної консолідації (на прикладі газети кримських болгар «Извор»). Держава та регіони. Сер.: Гуманітарні науки. 2012. № 4 (31). C. 147-151. URL: http://nbuv. gov. ua/UJRN/drgn_2012_4_28 (дата звернення: 11.07.2020)

15. С. Орел. Преса національних меншин: без вини винувата. URL: https://rk. kr. ua/presa-natsionalnih-menshin-bez-vini-vinuvata (дата звернення: 11.07.2020)

16. Історія преси в Україні. URL: https://uk. wikipedia. org/wiki/ Історія_преси_в_Україні (дата звернення: 12.07.2020)

17. Статистичні дані про випуск друкованих 3MI у 1 півріччі 2019 року. URL: http://comin. kmu. gov. ua/control/uk/publish/ article?art_id=157433\&cat_id=85717 (дата звернення: 12.07.2020)

18. Друковані засоби масової інформації України URL: http://www. ukrbook. net/zmi. html (дата звернення: 12.07.2020)

19. Про кількість та склад населення Івано-Франківської області за підсумками Всеукраїнського перепису населення 2001 року. URL: http://2001.ukrcensus. gov. ua/results/general/nationality/ ivano-frankivsk/ (дата звернення: 07.07.2020)

20. Засоби масової інформації в Івано-Франківську. URL: https:// uk. wikipedia. org/wiki/Засоби_масової_інформації_в_ІваноФранківську (дата звернення: 09.07.2020) 
21. Литвин М.Р., Науменко К. Є. Історія ЗУНР. Львів: Інститут українознавства НАН України, ВКФ «Олір», 1995. С. 101.

22. Історія Івано-Франківська URL: https://uk. wikipedia. org/wiki/ Історія_Івано-Франківська (дата звернення: 13.07.2020)

23. Про поляків у Франківську і франківців у Польщі. URL: https://sotka. life/pro-poliakiv-u-frankivsku-i-frankivtsiv-upolshchi-rozpovidaiut-andzhej-leush-i-mar-ia-osidach/ (дата звернення:10.07.2020)

24. Центр польської культури та європейського діалогу в ІваноФранківську URL: https://www. ckpide. eu/ua/aktualnosci/ wydarzenia/2762-aktyvnist-molodykh-poliakiv-v-ukrainskykhrealiiakh (дата звернення: 04.07.2020)

25. Кур'єр Галіційський. URL: https://uk. wikipedia. org/wiki/ Кур\%27єр_Галіційський (дата звернення: 1.07.2020)

26. Хто ми? URL: https://www. kuriergalicyjski. com/o-nas/135-o-nas (дата звернення: 02.07.2020)

27. 3 життя пішов засновник найбільшої польської газети в Україні Мірослав Ровіцький. URL: https://detector. media/community/ article/178673/2020-07-10-z-zhittya-pishov-zasnovnik-naibilshoipolskoi-gazeti-v-ukraini-miroslav-rovitskii/ (дата звернення: 06.07.2020)

28. В Івано-Франківсъку відкрили угорсъкий культурно-освітній центр. URL: https://mi10o.info/2020/o1/24/v-ivano-frankivskuvidkryly-ugorskyj-kulturno-osvitnij-tsentr (дата звернення: 06.07.2020)

\section{References}

1. Yakubova L. D. Natsionalni menshyny Ukrainy. Entsyklopediia istorii Ukrainy: T. 7: Mi-O / Redkol.: V. A. Smolii (holova) ta in. NAN Ukrainy. Instytut istorii Ukrainy. K.: V-vo «Naukova dumka», 2010. 728 s. URL: http://www. history. org. ua/?termin=Natsionalni_ menshyny (data zvernennia: 01.07.2020)

2. Bezverkha T.M. Periodychni vydannia natsionalnykh menshyn Zhytomyrskoi oblasti yak chynnyk etnointehratsii hromadianskoho suspilstva v Ukraini. Naukovi zapysky Instytutu zhurnalistyky. 2016. T.63.S.64-67.URL:http://nbuv.gov.ua/UJRN/Nzizh_2016_63_14 (data zvernennia: 03.07.2020)

3. Dutsyk D., Dvorovyi M. Natsionalni menshyny Ukrainy i media: do porozuminnia cherez tolerantnist. Posibnyk dlia zhurnalistiv ta zhurnalistok. Kyiv: TOV «SIHMATREID», 2019. S.5. 
4. Zakon Ukrainy «Pro natsionalni menshyny v Ukraini» URL: http:// zakon2.rada. gov. ua/laws/show/2494-12 (data zvernennia: 04.07.2020)

5. Lutsyshyn H. I. Natsionalni menshyny u politychnomu zhytti Ukrainy: dys.... kand. polit. Nauk. Lviv, 2002. $190 \mathrm{~s}$.

6. Lutsyshyn H. I. Natsionalna konsolidatsiia Ukrainy $\mathrm{v}$ umovakh suchasnoho politychnoho protsesu. Lviv: Vydavnytstvo Lviv. Politekhniky, 2012. $361 \mathrm{~s}$.

7. Lopushynskyi I. P. Ukraina i natsionalni menshyny: shliakh do tolerantnosti ta spivpratsi. Aktualni problemy derzhavnoho upravlinnia pedahohiky ta psykholohii. Zbirnyk naukovykh prats Khersonskoho natsionalnoho tekhnichnoho universytetu. Kherson, 2013. Vyp. 1 (9). S. 99-103.

8. Rafalskyi O. O. Natsionalni menshyny $\mathrm{v}$ Ukraini $\mathrm{v}$ KhKh stolitti: istoriohrafiia: dys.... d-ra ist. Nauk. K., 2001. $462 \mathrm{~s}$

9. Chyrko B. V. Natsionalni menshyny Ukrainy (20-30 roky KhKh st. ). K.: Asotsiatsiia «Ukraina», 1995.

10. Mironova I. S. Natsionalni menshyny Ukrainy: Navch.-metod. posib. Mykolaiv; Odesa: TOV ViD, 2006. $305 \mathrm{~s}$.

11. Kolisnyk Yu. V. Presa natsionalnykh menshyn Ukrainy yak zasib yikh samostverdzhennia v umovakh stanovlennia ukrainskoi derzhavnosti (1992-1999 rr. ): dys...kand. filol. nauk. L., 2000.173 s.

12. Mialovytska N. Prava natsionalnykh menshyn: yevropeiskyi dosvid. URL: http://www. viche. info/ journal/3839/. (data zvernennia: 09.07.2020)

13. Riaboshapka L. Pravove stanovyshche natsionalnykh menshyn Ukrainy (1917-2000). Lviv, 2001.

14. Shvets V.M. Presa natsionalnykh menshyn Ukrainy yak chynnyk etnichnoi konsolidatsii (na prykladi hazety krymskykh bolhar «Yzvor»). Derzhava ta rehiony. Ser.: Humanitarni nauky. 2012. № 4 (31). S. 147-151. URL: http://nbuv. gov. ua/UJRN/drgn_2012_4_28 (data zvernennia: 11.07.2020)

15. S. Orel. Presa natsionalnykh menshyn: bez vyny vynuvata. URL: https://rk. kr. ua/presa-natsionalnih-menshin-bez-vini-vinuvata (data zvernennia: 11.07.2020)

16. Istoriia presy $\mathrm{v}$ Ukraini. URL: https://uk. wikipedia. org/wiki/ Istoriia_presy_v_Ukraini (data zvernennia: 12.07.2020)

17. Statystychni dani pro vypusk drukovanykh ZMI u 1 pivrichchi 2019 roku. URL: http://comin. kmu. gov. ua/control/uk/publish/ article?art_id=157433\&cat_id=85717 (data zvernennia: 12.07.2020)

18. Drukovani zasoby masovoi informatsii Ukrainy URL: http://www. ukrbook. net/zmi. html (data zvernennia: 12.07.2020) 
19. Pro kilkist ta sklad naselennia Ivano-Frankivskoi oblasti za pidsumkamy Vseukrainskoho perepysu naselennia 2001 roku. URL: http://2001.ukrcensus. gov. ua/results/general/nationality/ivanofrankivsk/ (data zvernennia: 07.07.2020)

20. Zasoby masovoi informatsii v Ivano-Frankivsku. URL: https:// uk. wikipedia. org/wiki/Zasoby_masovoi_informatsii_v_IvanoFrankivsku (data zvernennia: 09.07.2020)

21. Lytvyn M. R., Naumenko K. Ye. Istoriia ZUNR. Lviv: Instytut ukrainoznavstva NAN Ukrainy, VKF «Olir», 1995. S. 101.

22. Istoriia Ivano-Frankivska URL: https://uk. wikipedia. org/wiki/ Istoriia_Ivano-Frankivska (data zvernennia: 13.07.2020)

23. Pro poliakiv u Frankivsku i frankivtsiv $u$ Polshchi. URL: https://sotka. life/pro-poliakiv-u-frankivsku-i-frankivtsiv-upolshchi-rozpovidaiut-andzhej-leush-i-mar-ia-osidach/ (data zvernennia:10.07.2020)

24. Tsentr polskoi kultury ta yevropeiskoho dialohu v Ivano-Frankivsku URL: https://www. ckpide. eu/ua/aktualnosci/wydarzenia/2762aktyvnist-molodykh-poliakiv-v-ukrainskykh-realiiakh (data zvernennia: 04.07.2020)

25. Kurier Halitsiiskyi. URL: https://uk. wikipedia. org/wiki/Kur\%27ier_ Halitsiiskyi (data zvernennia: 1.07.2020)

26. Khto my? URL: https://www. kuriergalicyjski. com/o-nas/135-o-nas (data zvernennia: 02.07.2020)

27. Z zhyttia pishov zasnovnyk naibilshoi polskoi hazety $\mathrm{v}$ Ukraini Miroslav Rovitskyi. URL: https://detector. media/community/ article/178673/2020-07-10-z-zhittya-pishov-zasnovnik-naibilshoipolskoi-gazeti-v-ukraini-miroslav-rovitskii/ (data zvernennia: 06.07.2020)

28. V Ivano-Frankivsku vidkryly uhorskyi kulturno-osvitnii tsentr. URL: https://mi10o.info/2020/01/24/v-ivano-frankivsku-vidkrylyugorskyj-kulturno-osvitnij-tsentr (data zvernennia: 06.07.2020)

Стаття надійшла до редакциї 12.10.2O

(C) Матвієнків C. M., 2020 